\title{
Ancient Italian artefacts get the blues
}

\section{Scientists accuse officials of neglect as chemicals discolour stored relics.}

A mysterious blue sheen that is creeping over precious archaeological artefacts has sparked a political firestorm in Italy. Scientists are battling local authorities to save the damaged collection - and determine who is to blame.

The prehistoric treasures including human bones and stone tools - come from sites near Verona, which were inhabited by some of Europe's last known Neanderthals when anatomically modern humans were beginning to dominate the region. Scientists say that comparing DNA from the remains with DNA from Neanderthal bones found elsewhere may show how the last Neanderthals moved across the continent seeking refuge, for example.

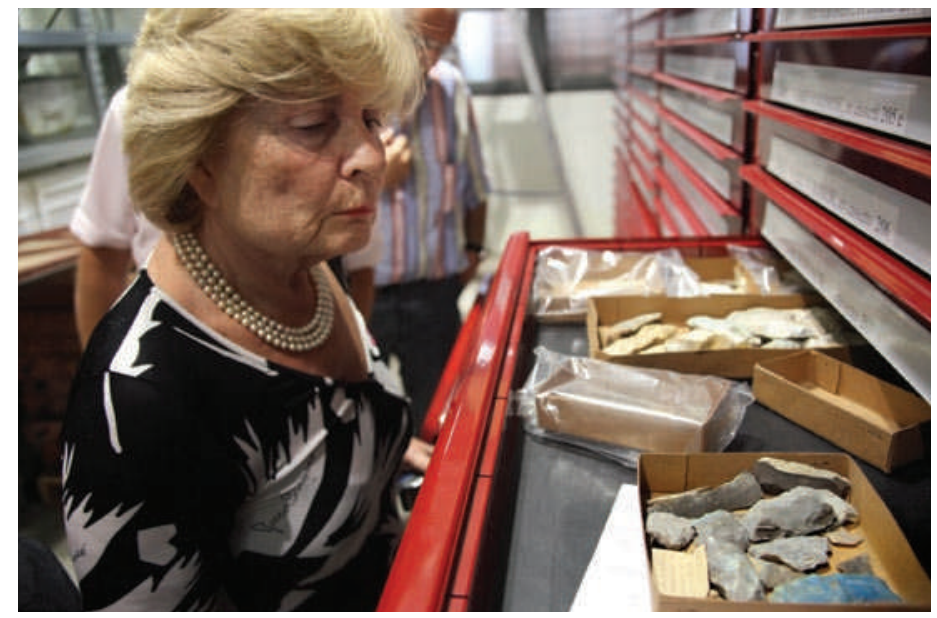

Erminia Perbellini, councillor for culture for Verona, inspects discoloured flints. culture, demanding that the artefacts be immediately transferred to safe premises. They are also calling for an expert committee to assess the damage, and for an investigation to identify who is responsible for endangering the collection - potentially a crime under Italy's strict laws on cultural heritage.

Reid Ferring, a geologist and archaeologist at the University of North Texas in Denton, says he signed the petition because he finds it "devastating that the collection with such a high scientific value has been damaged".

But now some of the remains face irreparable damage, as they lie deteriorating in a former military armoury in northern Italy. The artefacts were moved there in 2007 and 2008 after Verona's town council sold their original home - an eighteenth-century castle that provided

overflow storage for Verona's Natural History Museum. The money from the sale was intended to refurbish the arsenal to provide a new home for all of the museum's collections, but the funds were subsequently reallocated.

Concerned scientists are about to send a petition to Sandro Bondi, Italy's minister of He points out that Verona is a World Heritage Site. "You would think they would have paid better attention to their historic collections."

The collection's curator, Laura Longo - who declined to comment to Nature because she has been asked by the museum not to speak to the press - first became concerned when she

\section{Universities shun Europe's drug initiative}

Europe's pharmaceutical industry, struggling with huge research costs and unfriendly regulation, has been limping along for more than a decade. To help the ailing sector, the European Union (EU) in 2007 launched the multibillion-euro Innovative Medicines Initiative (IMI) to bring public and private researchers together and speed up drug development.

But the partnership is now looking less than healthy. Many universities and public research institutes are complaining that the high cost of participation, and a raw deal on intellectual property (IP) rights, is stopping them from taking part.

In its first call for proposals, the IMI received 138 'expressions of interest' from universities and research institutes across 18 research topics. In the second call, it garnered 124 expressions of interest over 9 research topics - a resounding success, says the IMI's executive office in Brussels.

Yet as the IMI prepares to launch its third call this autumn, a group of 11 leading university and research organizations has published a joint statement saying that the call is unlikely to succeed unless the funding and IP rules are changed. The 6 July statement says that, owing to these concerns, participation in the first two rounds has been well below potential.

The research organizations say that they have repeatedly expressed their concerns to the European Commission (EC) and to the IMI's managing bodies over the past two years, but have seen no progress. Pauline Bastidon, a policy officer at the European Association of Research and Technology Organisations, a trade association which co-signed the statement, says that some universities have been forced to give away potentially valuable IP rights in order to take part in projects.

The IMI is one

of five ambitious applied-research programmes known as Joint Technology Initiatives (JTIs) - the flagships of the EU's $€ 50$-billion (US\$63-billion) Seventh Framework Programme (FP7), which runs until 2013. The EC conceived the JTIs to help promote research collaborations between academia and industry and to translate basic science into potentially lucrative technologies. Each JTI draws up its own rules on funding and IP. In the case of the IMI, the research agenda is largely determined by industry.

"One of the key objectives of IMI is to deliver innovative medicines to patients in a faster way, by speeding up discovery and development in the "One of the key objectives pharmaceutical of IMI is to deliver innovative medicines to sector," says Michel Goldman, executive director of the IMI. Its IP policy

"was designed to promote swift disclosure and exploitation of new knowledge", he says.

But universities say that they are loath to join an IMI project which generates IP that they cannot own. Unless the IMI revises its IP strategy, it is unlikely that new drugs will be developed from these projects, says Thierry Troosters, a researcher at the Catholic University of Leuven 
gained brief access to the relocated artefacts in February, and found that some of the flint tools were turning bright blue. She then provided four samples of the discoloured flint to Gilberto Artioli, a geo-archaeologist at the University of Padua, for chemical analysis.

Over the next three months, she reported the problem to the museum's director and also to Vincenzo Tine, the regional representative of the ministry of culture in Venice. Last month
"You would think they would have paid better attention to their historic collections."
Artioli says. But the results would be political dynamite. If the contaminant came from the walls or floor of the building, the municipality of Verona could be guilty of allowing cultural heritage items to be transferred to a building that had not been properly checked for pollutants.

Tine, whose office is responsible for ensuring compliance with cultural-heritage laws in the Veneto region, suggests that the source of the she sent a formal report to Stefano de Caro, the ministry's general director for archaeology in Rome, and to the department of military police concerned with crimes against cultural heritage. That department has already referred the case to Verona's public prosecutors.

Meanwhile, Artioli's first analyses quickly showed that the samples - and also the cardboard they were delivered in - were impregnated with hydrocarbons, which he says may come from petrol, or from lubricants once stored at the arsenal and used to keep the weapons there in working order. "But this did not explain the blue colour," he says. $\mathrm{He}$ suspects that hydrocarbon vapours carried a pollutant onto the flints, where it reacted to form a "very stable and durable" blue pigment that was previously unknown.

More chemical detective work could easily determine the source of this pollutant, pollutant may be the padding in the storage cabinets acquired for the artefacts in their new premises. He also plays down the seriousness of the problem. "Only a hundred or so of the millions of objects in the collections have turned blue, and they can easily be restored to their original colour," he says.

But scientists see things very differently. "Up to $30 \%$ of the flints are turning blue," says Artioli. "Sure, we can bleach the colour out, but then palaeontologists will never be able to do any meaningful analysis from a chemical point of view." And although they have not changed colour, the bones and pottery are more porous than the stone tools and therefore will have a deeper exposure to the chemical pollutants, he says. "Now the summer temperatures are accelerating the chemical transformation," he adds. "The matter is urgent."

Alison Abbott in Belgium. Troosters is taking part in an IMI project to gather information from patients with pulmonary disease to ascertain what physical activity aids their recovery. He says that he designed his study proposal to omit any technologies or concepts that the university itself hopes to exploit.

Universities also complain that the programme allows them to claim back only $20 \%$ of the indirect costs of a project, including infrastructure and computing support. By contrast, other FP7 projects reimburse universities with at least $60 \%$ of their indirect costs.

Linda Polik, European adviser at the research services unit of the University of Oxford, UK, says that although the university expressed interest in five projects in the first IMI funding round, it did not participate in the second call because it could not afford to cover the indirect costs. She says that the university will only participate in the third round if interested departments can make up the funding shortfall from elsewhere and state a case for doing so, given the unfavourable IP rules.

"We are aware that some organizations have concerns," says Goldman. But, he notes, "155 academic and other research organizations are already participating in ongoing IMI projects under the current IP policy, and the general feedback we get from project participants is positive".

Goldman adds that the IMI has already published guidance to help applicants in the IP negotiation process, and is due to update that information before the next funding call. And the EC, which has representatives on the IMI's governing board, is assessing the impact of the $20 \%$ costs cap.

Yet for those institutions that have participated in the IMI, it has been a bruising experience that they say is deterring others from joining. Ulf Johann, legal adviser to the Fraunhofer Society, a research organization in Munich, Germany, says that last-minute changes to a legal agreement governing the society's participation in an IMI project to develop biomarkers forced it to give up all rights to any research royalties. Johann says that the society had been threatened with exclusion from the project if it did not sign.

"People might remember [the IMI] more for the problems over IP than for providing new medicines," he says.

Natasha Gilbert 